Issues in World Politics 


\title{
Issues in World Politics
}

\author{
Brian White, Richard Little \\ and Michael Smith
}

Editors

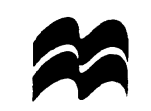

Macmillan Education 
ISBN 978-0-333-67651-6 ISBN 978-1-349-25639-6 (eBook)

DOI 10.1007/978-1-349-25639-6

ISSUES IN WORLD POLITICS

Selection, editorial matter and Chapters 1 and 12 copyright (C) 1997 by

Brian White, Richard Little and Michael Smith

Individual chapters (in order) copyright $\odot$ Mark Webber, Alan Russell, Michael Smith, Caroline Thomas, Melvyn Reader, Joanna Spear,

Michael Pugh, Stephen Ryan, Anoushiravan Ehteshami, Sita Bali, John Vogler 1997

Softcover reprint of the hardcover 1st edition 1997 978-0-333-67650-9

All rights reserved. No part of this book may be used or reproduced in any manner whatsoever without written permission except in the case of brief quotations embodied in critical articles or reviews.

For information, address:

St. Martin's Press, Scholarly and Reference Division, 175 Fifth Avenue, New York, N.Y. 10010

First published in the United States of America in 1997

This book is printed on paper suitable for recycling and made from fully managed and sustained forest sources.

ISBN 978-0-312-17547-4 (cloth)

ISBN 978-0-312-17548-1 (paper)

Library of Congress Cataloging-in-Publication Data

Issues in world politics / edited by Brian White, Richard Little, and Michael Smith.

p. $\mathrm{cm}$.

Includes bibliographical references and index.

ISBN 978-0-312-17547-4 (cloth). — ISBN 978-0-312-17548-1 (paper)

1. World politics-1989- I. White, Brian. II. Little, Richard.

III. Smith, Michael, 1947-

D860.I87 1997

909.82'4-dc21 


\section{Contents}

Preface ix

Notes on the Contributors $\quad \mathrm{xi}$

List of Abbreviations xiv

1 Issues in World Politics

Brian White, Richard Little and Michael Smith 1

The End of the Cold War and a New Global Agenda? 2

Issues and Problems 4

Issues, Agendas and Agenda-Setting $\quad 6$

Issues and the Media $\quad 8$

Types of Issues $\quad 12$

The Significance of Issues in World Politics 15

The Management of Issues in World Politics 18

Selection of Issues and Key Questions $\quad 21$

2 States and Statehood

Mark Webber $\quad 24$

The Nature of Statehood: Organization and Practice 26

Statehood as a Problem in World Politics 30

Statehood and the Post-Cold War World 35

Statehood and Contemporary World Politics 42

3 Trade, Money and Markets

Alan Russell $\quad 45$

Economic Interdependence: A Set of Issues 46

The Scope and Intensity of Economic Interdependence $\quad 48$

General Problems of Economic Interdependence 53

Putting Issues of Economic Interdependence on the International Agenda 
Economic Interdependence and the End of the Cold War

Managing Global Economic Interdependence

Economic Interdependence and Contemporary World Politics

4 Regions and Regionalism

Michael Smith

Regions and Regionalism: Characteristics and Driving Forces

Problems of Regionalism

Regions, Regionalism and the International Agenda 81

Regionalism in the Post-Cold War World 82

Managing Regionalism

Regions and Regionalism: Implications for World

Politics

5 Development and Inequality

Caroline Thomas and Melvyn Reader

Issues of Development and Inequality 93

Problems of Development and Inequality 95

Development and Inequality on the International Agenda

Development and Inequality in the Post-Cold War World

Managing Issues of Development and Inequality

Development, Inequality and World Politics

\section{Arms and Arms Control}

$$
\text { Joanna Spear }
$$

The Significance of Arms and Arms Control Issues

General Problems of Arms and Weapons-Related

Issues

Arms and Arms Control on the International Agenda

Arms Control Issues after the Cold War

International Control Mechanisms 
Arms, Arms Control and Contemporary World Politics

\section{Peacekeeping and Humanitarian Intervention}

Michael Pugh

International Peace Support as an Issue

International Peace Support: General Problems

The Location of Peace Support on the International Agenda

Peacekeeping and Humanitarian Intervention after the Cold War

International Management

Peace Support and Contemporary World Politics

8 Nationalism and Ethnic Conflict Stephen Ryan

Ethno-Nationalist Conflict as an Issue

General Problems of Nationalism and Ethnic Conflict

Putting Ethno-Nationalist Conflict on the International Agenda

Nationalism, Ethnic Conflict and the End of the Cold War

Managing Ethnic Conflict

Nationalism, Ethnic Conflict and Contemporary

World Politics

\section{Islamic Fundamentalism and Political Islam} Anoushiravan Ehteshami

The Diverse World of Islam

Different Perspectives on Islamic Fundamentalism

Reassessing Islamic Fundamentalism

Fighting for the Muslim World

Putting Islamic Fundamentalism on the International Agenda 
viii

Contemporary World Politics: Globalization v.

Fundamentalism

10 Migration and Refugees

Sita Bali

Migration as an International Issue $\quad 200$

People on the Move $\quad 203$

New Patterns of Migration 205

The Pros and Cons of Migration 207

Putting Migration and Refugees on the International Agenda $\quad 214$

Institutional Responses to Migration and Refugees 217

Migration and Contemporary World Politics 220

11 Environment and Natural Resources

John Vogler 222

International Awareness: From Stockholm to Rio 223

The Rising Profile of Environmental Issues 225

Defining the Problem 232

The role of International Cooperation 233

Getting on the International Agenda 236

Environmental Issues after the Cold War $\quad 237$

Managing Environmental Problems 239

The Environment and Contemporary World Politics 242

12 Issues in World Politics Reviewed Brian White, Richard Little and Michael Smith 246

The Selection of Issues $\quad 247$

Links between Issues 251

Issues and Contemporary World Politics 253

Conclusion 265

Bibliography 268

Index 283 


\section{Preface}

One of the exciting and challenging effects of the 'modularization' of undergraduate programmes is the growing number of students sampling areas of study outside their main field(s), particularly in the first year of study. In common with many other academics, the challenge for university teachers of International Relations/World Politics is to devise and write introductory textbooks that will not only serve the interests of specialist students but will also appeal to a wider range of undergraduates fascinated by particular aspects of the contemporary world but who may not want to pursue the subject further.

This book attempts to meet that challenge by adopting as its focus the range of issues that are at the heart of the agenda of contemporary world politics. The working assumption here is that issues which are often the subject of topical debate and media coverage provide an important point of access to world politics for a large number of students. The book therefore seeks to build upon some knowledge and an existing interest not only by providing relevant information and a context for making sense of particular issues but also by explicitly addressing the question of what these issues collectively tell us about the nature of world politics at the end of the twentieth century.

What began as an idea and a challenge could only develop to a successful conclusion with the cooperation of a number of people. Steven Kennedy, our publishing editor, gave the project enthusiastic support and encouragement from start to finish. Brian White succeeded in tempting Richard Little and Michael Smith to share editorial duties while undertaking to manage the project. The editors in turn were delighted to receive the support of experts on particular issues who rose to the challenge of writing for nonspecialist as well as specialist students and managed to stick to the common format and a very tight set of deadlines. Edited volumes can be a difficult experience for editors but in this case it was a 
pleasure - for which many thanks to the contributors. Grateful thanks are also due to Sheila Berrisford, Jean Edwards and Barbra Georgellis who all provided crucial help and support at various stages of the project.

Brian White
Richard Little
Michael SMith 


\section{Notes on the Contributors}

Sita Bali is a Senior Lecturer in International Relations at Staffordshire University. Her doctoral research explored the international political implications of migration through an examination of the British Sikh community, and she is the author of a forthcoming book on the politics of the Sikh diaspora titled Sikhs: The Search for Statehood. She has also written articles on Indian politics.

Anoushiravan Ehteshami is Reader in International Relations and Director of Postgraduate Studies at the Centre for Middle East and Islamic Studies, University of Durham. His recent publications include (as co-editor) Islamic Fundamentalism (1996); After Khomeini: The Iranian Second Republic (1995); and (as editor) From the Gulf to Central Asia: Players in the New Great Game (1994). His latest book (with Professor Hinnebusch) is Syria and Iran: Middle Powers in a Penetrated Regional System (1997)

Richard Little is Professor of International Politics at the University of Bristol. He has also taught at the Open University and Lancaster University and was the editor of the Review of International Studies from 1990 to 1994 . He has written extensively in the area of international relations theory and his publications include (with Robert McKinlay) Global Politics and World Order (1986) and (with Barry Buzan and Charles Jones) The Logic of Anarchy (1993).

Michael Pugh is a Senior Lecturer in the Department of Politics at the University of Plymouth. He is the editor of the journal International Peacekeeping and has written or edited works on maritime security issues and humanitarianism and peacekeeping, including Maritime Security and Peacekeeping (1995); 'Humanitarianism and Peacekeeping', Global Society $(10: 3,1996)$; and The UN, Peace and Force (1997). 
Melvyn Reader is currently completing a Ph.D. in the Department of Politics at the University of Southampton. His doctoral thesis is on "The Rise of Protestant "Fundamentalism" in World Politics: A Case Study of Brazil', which examines the relationship between the impact of globalization on development and the growth of religious fundamentalism in the 'South'.

Alan Russell is a Senior Lecturer in International Relations at Staffordshire University. He is the author of The Biotechnology Revolution: An International Perspective (1988). His recent publications include 'Merging Technological Paradigms and the Knowledge Structure in the International Political Economy' in Science and Public Policy (22:2, 1995), and 'Technology as Knowledge: Generic Technology and Change in the Global Political Economy', in Talalay et al. (eds), Technology, Culture and Competitiveness and the Global Political Economy (1996).

Stephen Ryan is a Senior Lecturer in the School of History, Philosophy and Politics at the University of Ulster. He is the author of Ethnic Conflict and International Relations (2nd edn, 1995) and has written several chapters and articles on the themes of ethnic conflict, conflict resolution and international relations.

Michael Smith is Professor of European Politics and Jean Monnet Chair holder in the Department of European Studies at Loughborough University. He was previously Professor of International Studies and Dean of the School of International Studies and Law at Coventry University. His publications include (edited with Richard Little) Perspectives on World Politics (2nd edn, 1991); (with Stephen Woolcock) The United States and the European Community in a Transformed World (1993); and (with Brian Hocking) World Politics: An Introduction to International Relations (2nd edn, 1995).

Joanna Spear is a lecturer in the Department of War Studies at King's College, London. She recently returned from two years as a research fellow at the Center for Science and International Affairs, Harvard University. Her most recent publications are Carter and Arms Sales: Implementing the Carter Administration's Arms Transfer Restraint Policy (1995), and 'The Role of Arms 
Limitations and Confidence and Security Building Measures', in Brown (ed.), The International Dimensions of Internal Conflict (1996).

Caroline Thomas is Reader in Politics at the University of Southampton and her primary research interest is in the 'South' in international relations. Her recent publications include (with Peter Wilkin as co-editor) Globalization and the South (1996); (as editor) Rio: Unravelling the Consequences (1994); and The Environment in International Relations (1992).

John Vogler is Professor of International Relations at Liverpool John Moores University. Since 1990 he has been the Convener of the BISA Environment Group and a member of the Economic and Social Research Council Global Environmental Change Programme Committee. His recent publications include The Global Commons: A Regime Analysis (1995) and (with Mark Imber as co-editor) The Environment and International Relations (1996)

Mark Webber is a lecturer in the Department of European Studies at Loughborough University. His recent publications include The International Politics of Russia and the Successor States (1996); 'Coping with Anarchy: Ethnic Conflict and International Organizations in the Former Soviet Union', International Relations (13:1, 1996); and 'The Soviet Union, Russia and 1945: One Step Forward, Two Steps Back', Journal of Area Studies (7, 1995).

Brian White is Professor of International Relations and Head of International Relations and Politics at Staffordshire University. His publications include Britain, Detente and Changing EastWest Relations (1992); (with Michael Clarke as co-editor) Understanding Foreign Policy: A Foreign Policy Systems Approach (1989); and (with Michael Smith and Steve Smith as co-editors) British Foreign Policy: Tradition, Change and Transformation (1988). 


\section{List of Abbreviations}

AIDS

AMRAAMs

AOSIS

APEC

ASEAN

BAe

BMD

BWC

CAAT

CAFOD

CBW

CCW

CFCs

CITES

CMEA

CoCom

CSD

CTBT

CWC

DHA

ECO

ECOWAS

ERM

ETA

EU

FAO

FCCC

FDI

G-7

GATT

GDO

GDR

GEC
Acquired Immune Deficiency Syndrome

Advanced, Medium-Range, Air-to-Air Missiles

Association of Small Island States

Asia-Pacific Economic Cooperation

Association of South-east Asian Nations

British Aerospace

Ballistic Missile Defence

Biological and Toxin Weapons Convention

Campaign Against the Arms Trade

Catholic Fund for Overseas Development

Chemical and Biological Weapons

Convention on Conventional Weapons

Chlorofluorocarbons

Convention on Trade in Endangered Species

Council for Mutual Economic Assistance

Coordinating Committee on Multilateral Export

Controls

Commission for Sustainable Development (of the UN)

Comprehensive Test Ban Treaty

Chemical Weapons Convention

Department of Humanitarian Affairs (of the UN)

Economic Cooperation Organization

Economic Community of West African States

Exchange Rate Mechanism

Euskadi ta Askatasuna

European Union

Food and Agriculture Organization (of the UN)

Framework Convention on Climate Change

Foreign Direct Investment

Group of Seven

General Agreement on Tariffs and Trade

Grassroots Development Organization

German Democratic Republic

Global Environmental Change 


$\begin{array}{ll}\text { GNP } & \text { Gross National Product } \\ \text { HCFC } & \text { Hydrochloroflourocarbon } \\ \text { ICES } & \text { International Council for the Exploration of the } \\ & \text { Seas } \\ \text { ICO } & \text { Islamic Conference Organization } \\ \text { ICPF } & \text { International Commission on Peace and Food } \\ \text { ICRC } & \text { International Committee of the Red Cross } \\ \text { ICTY } & \text { International Criminal Tribunal for the former } \\ & \text { Yugoslavia } \\ \text { IFOR } & \text { Implementation Force (of NATO) } \\ \text { IFRC } & \text { International Federation of the Red Cross and Red } \\ & \text { Crescent Societies } \\ \text { IGO } & \text { Intergovernmental Organization } \\ \text { IMF } & \text { International Monetary Fund } \\ \text { IMO } & \text { International Maritime Organization } \\ \text { INGO } & \text { International Non-Governmental Organization } \\ \text { IPCC } & \text { Intergovernmental Panel on Climate Change } \\ \text { IPE } & \text { International Political Economy } \\ \text { IRA } & \text { Irish Republican Army } \\ \text { IUCN } & \text { International Union for the Conservation of } \\ & \text { Nature } \\ \text { LDC } & \text { Less Developed Country } \\ \text { MARPOL } & \text { Convention for the Prevention of Pollution from } \\ & \text { Ships } \\ \text { MENA } & \text { Middle East and North Africa } \\ \text { MERCOSUR } & \text { Mercado Comun del Cono Sur (Southern } \\ & \text { Common Market) } \\ \text { MNC } & \text { Multinational Corporation } \\ \text { MPLA } & \text { Movimento Popular de Libertação de Angola } \\ \text { MTCR } & \text { Missile Technology Control Regime } \\ \text { NAFTA } & \text { North American Free Trade Agreement } \\ \text { NATO } & \text { North Atlantic Treaty Organization } \\ \text { NGO } & \text { Non-Governmental Organization } \\ \text { NIC } & \text { Newly-Industrializing Country } \\ \text { NPT } & \text { Nuclear Non-Proliferation Treaty } \\ \text { NSG } & \text { Nuclear Suppliers Group } \\ \text { OAS } & \text { Organization of American States } \\ \text { OAU } & \text { Organization of African Unity } \\ \text { OECD } & \text { Organization for Economic Cooperation and } \\ & \text { Development } \\ & \end{array}$




\section{OSCE}

P5

PLO

RPF

SALT

SAP

SIPRI

TNB

UAE

UN

UNCED

UNCTAD

UNDP

UNEP

UNGA

UNHCR

UNICEF

UNIDO

UNITA

UNPROFOR

UK

US

USSR

VAT

WCED

WEU

WMD

WMO

WTO
Organization for Security and Cooperation in Europe

Permanent Five Members of the UN Security

Council

Palestine Liberation Organization

Rwandan Patriotic Front

Strategic Arms Limitation Talks

Structural Adjustment Programme

Stockholm International Peace Research Institute

Transnational bank

United Arab Emirates

United Nations

United Nations Conference on Environment and

Development

United Nations Conference on Trade and

Development

United Nations Development Programme

United Nations Environment Programme

United Nations General Assembly

United Nations High Commission for Refugees

United Nations International Children's

Emergency Fund

United Nations Industrial Development

Organization

União Nacional para a Independencia de Angola

United Nations Protection Force

United Kingdom

United States

Union of Soviet Socialist Republics

Value-Added Tax

World Commission on Environment and

Development

Western European Union

Weapons of Mass Destruction

World Meteorological Organization

World Trade Organization 